Grzegorz HOŁUB

PAT Kraków

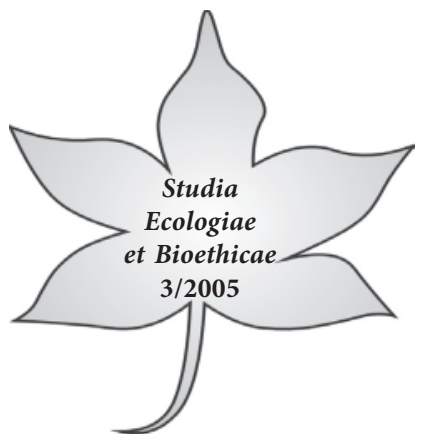

\title{
Debata na temat koncepcji osoby w bioetyce
}

Rozwój współczesnej myśli bioetycznej zdominowany jest przez tendencję do porzucenia wszelkich systematycznych analiz i koncentracji na poszczególnych problemach. W znacznej mierze wynika to z pragmatycznego przekonania, że bioetyka powinna zająć się bardziej rozwiązywaniem przypadków niż teorią etyczną. Teza ta posiada swoje uprzywilejowane miejsce w myśli amerykańskiej, a szczególnie w kazuistyce ${ }^{1}$. Miarodajna w tej kwestii wydaje się następująca wypowiedź A. Jonsena: „Opieka medyczna dotyczy przypadków. Ma się bowiem zawsze do czynienia z chorobą i kuracją poszczególnych osób, cierpiących na konkretne choroby. Filozofowie i teologowie, zaangażowani w opieką medyczną, na początku próbowali odwoływać się do standartowych teorii etycznych w analizie problemów pojawiających się w trakcie terapii. Jednak w końcu przyznali oni, że dyskutują na temat przypadków, a nie teorii. Dlatego zrodziło to potrzebę wypracowania takiego podejścia, dzięki któremu w centrum analiz znajdzie się konkretny problem, a nie ogólna teoria etyczna"2.

Dalszy rozwój bioetyki wykazał jednak, że przekonanie to posiada wątpliwą wartość. Okazało się bowiem, że wielu szczegółowych problemów, jakie pojawiają się w procesie terapii, nie można rozwiązać, gdy brak jest odwołania do szerszego rozumienia pewnych zasadniczych pojęć. Jednym z tych kluczowych terminów jest pojęcie osoby ${ }^{3}$. Wynika to $\mathrm{z}$ faktu, że całość badań, jakie podejmuje bioetyka właściwie oscyluje wokół problemów ludzkiego życia ${ }^{4}$. Stąd zrozumienie człowieka w jego wyjątkowości i niepowtarzalności stało się wymogiem naprawdę palącym.

A. Smith Iltis, Bioethics as Methodological Case Resolution: Specification, Specified Principlism and Casuistry, „The Journal of Medicine and Philosophy” 25(2000) 3, 283.

2 A. R. Jonsen, Casuistry, w: The Encyclopedia of Bioethics, red. W. T. Reich, t. I, Simon Schuster Macmillan, New York 1995, 348.

3 K. Doran, Person - A Key Concept for Ethics, „Linacre Quarterly” vol. 56(1989) 4, 38. Potwierdzeniem tej opinii jest wypowiedź Mahowald, która na łamach Encyklopedii bioetycznej - abstrahując jeszcze w tym miejscu od materialnego rozumienia pojęcia osoby - stwierdza: (...) the concept of person is of great significance to a variety of issues in contemporary bioethics. Zob. M. B. Mahowald, Person, w: The Encyclopedia of Bioethics, red. W. T. Reich, t. IV, Simon \& Schuster MacMillan, New York 1995, 1940.

4 Teza ta funkcjonuje w obrębie bioetyki rozumianej jako węższy typ refleksji nad zagadnieniami życia, abstrahując nieco od problemów właściwych dla etyki środowiskowej. 
Wielu współczesnych bioetyków podjęło się zadania ponownego przemyślenia zagadnień związanych z ludzkim życiem osobowym. W trakcie tego procesu pojawiło się parę zasadniczych tendencji $\mathrm{w}$ formułowaniu koncepcji osoby. Idąc za analizami S. K. Hellsten, można wskazać na trzy zasadnicze podejścia: koncepcję naturalistyczną, komunitarystyczną i humanistyczną ${ }^{5}$ Jak się później okaże, propozycje te będą jedynie punktem wyjścia w poszukiwaniu pełniejszych rozwiązań.

\section{Naturalistyczne myślenie o osobie}

Podejście naturalistyczne bazuje na podstawowym podziale, jakim jest rozróżnienie na człowieka (human being) i osobę (person) ${ }^{6}$. Pojęcie istoty ludzkiej, człowieka - w opinii myślicieli tego nurtu - posiada zaledwie deskryptywne odniesienie do poszczególnego członka rodzaju ludzkiego. Natomiast osoba posiada szczególną wartość, ponieważ jest ona żyjącą istotą, która charakteryzuje się posiadaniem świadomości i możliwością dokonywania wyborów. To rozumienie człowieka wywodzi się z myśli angielskiego empiryzmu, a szczególnie z definicji podanej przez J. Locka. Stwierdził on, że „osoba oznacza istotę myślącą i inteligentną, obdarzoną rozumem i zdolnością refleksji, istotę, która może ujmować siebie myślą jako samą siebie. (...) Może to czynić tylko dzięki świadomości swego «ja»"

We współczesnych nurtach naturalistycznych spotykamy się ze zbliżonymi formułami. Niekiedy są one repliką definicji Locka, czasami jednak wskazują na dodatkowe jakości, precyzujące rozumienie osoby. Współczesny empiryk $\mathbf{D}$. Parfit stwierdza, że, „aby być osobą, dana istota musi być świadoma samej siebie, świadoma swojej tożsamości i swojej egzystencji, która trwa w czasie"s. Inny myśliciel J. Harris w podobnym tonie stwierdza, iż „osobą jest jednostka, która jest zdolna do dokonania oceny swojego własnego życia. Takie dopiero istnienie - kontynuuje Harris - będzie zdolne do tego, aby utworzyć pojęcie samego siebie jako niezależnego centrum świadomości, które istnieje w czasie, z przyszłością, którą jest zdolne przewidzieć i chcieć jej przeżycia".

\footnotetext{
S. K. Hellsten, Towards an Alternative Approach to Personhood in the End of Life Questions, „Theoretical Medicine” 21(2000) 516-517.

6 Jeden z kanadyjskich filozofów Kluge tak uzasadnia tę dystynkcję: The identification of humanity and personhood is ethically suspect. Humanity is a biological concept defined in terms of genetic makeup. Personhood is ethical (...). Zob. J. E. Magnet, E-H. KLuge, Withholding Treatment from Defective Newborn Children, Brown Legal Publications, Inc., Cowamsville (Quebec) 1995, 166. J. Lock, Rozważania dotyczace rozumu ludzkiego, tłum. B. J. Gawecki, Warszawa 1955, 471.

D. PARfit, Reasons and Persons, Clarendon Press, Oxford 1984, 202.

9 J. HARris, In-Vitro Fertilisation. The Ethical Issues, „The Philosophical Quarterly” vol. 33(1983) $132,225$.
} 
P. Singer, idąc tym samym torem myślenia, wskazuje, że w takim razie za osoby należy uznać także wiele gatunków zwierząt, a szczególnie ssaków. Jego zdaniem, można wykazać, że stworzenia te są świadome swojej egzystencji w czasie i że są zdolne do rozumowania ${ }^{10}$. Dlatego „Homo sapiens - w opinii tego myśliciela - nie jest uprawniony do tego, aby być lepiej traktowanym niż stworzenia innych gatunków, które są na zbliżonym poziomie życia umysłowego" ${ }^{11}$.

Singer wskazuje ponadto na dodatkowe kryterium osoby, jakim jest zdolność do doznawania bólu i cierpienia. Kryterium to nieco rozszerza rozumienie osoby wskazując na dodatkowy, poza świadomościowo-wolitywny, aspekt. Istota, która posiada taką charakterystykę - w ujęciu tego filozofa - powinna być również uznana za osobę, ponieważ pojęcia tego (osoba) nie można ograniczyć tylko do czynników deskryptywnych (świadomości samego siebie, wolność). Singer próbuje dowieść, że fakt odczuwania cierpienia odsłania dodatkowo moralne znaczenie terminu „osoba” (It carries with it a certain moral standing) ${ }^{12}$.

Inny myśliciel w nurcie naturalistycznym, M. Tooley, wskazuje, że termin osoba powinien być prezentowany jako pojęcie deskryptywne (descriptive), a nie jako normatywne (evaluative) ${ }^{13}$. Innymi słowy chodzi oto, aby ukazać osobę w świetle takich własności, które pomijają jej charakter aksjologiczny i moralny. Aby więc uznać jakąś istotę za osobę musi ona posiadać takie oto kwalifikacje: zdolność do przewidywania własnej przyszłości, zdolność do rozumienia samego siebie (pojęcie istniejącego podmiotu doświadczeń i innych stanów mentalnych), bycie sobą (bycie istniejącym podmiotem doświadczeń), zdolność do samoświadomości, posiadanie (bieżące dysponowanie) samoświadomości ${ }^{14}$.

Jeden z pionierów współczesnej bioetyki, J. Fletcher, przedstawia aż 15 różnych atrybutów, jakie musi spełniać istota, pretendująca do miana osoby. Wskazuje on na takie jakości, jak: minimum inteligencji, samoświadomość, samokontrola, zmysł (poczucie) czasu, poczucie przyszłości, poczucie przeszłości, zdolność do wchodzenia w relacje $\mathrm{z}$ innymi, zatroskanie o innych, zdolność komunikowania, panowanie nad własnym istnieniem (aspekt wolności), zdolność do posiadania zainteresowania (curiosity), zdolność do dokonywania zmian i zmieniania się (change and changeability), posiadanie równowagi pomiędzy racjonalnością, a uczuciami, posiadanie tożsamości, niepowtarzalność, funkcjonowanie kory mózgowej ${ }^{15}$.

10 P. Singer, Rethinking Life and Death. The Collapse of Our Traditional Ethics, The Text Publishing Company, Melbourne 1994, 182.

11 P. Singer, Practical Ethics, Cambridge University Press, Cambridge 1993, 212.

12 Singer, Rethinking Life and Death. The Collapse of Our Traditional Ethics, dz. cyt., 182.

13 M. Tooley, Abortion and Infanticide, Clarendon Press, Oxford 1983, 35.

14 M. Tooley, A Defence of Abortion and Infanticide, w: The Problem of Abortion, red. J. Feinberg, Wadswoeth Publishing Company, Belmont 1973, 59-60.

15 J. Fletcher, Humanhood: Essays in Biomedical Ethics, Prometheus Books, New York 1979, 12-16. 
Przedstawione elementy charakteryzujące osobę można uporządkować, wskazując na parę istotnych aspektów. Pierwszym - i wydaje się, że dominującym - aspektem są czynniki związane ze świadomością i procesami myślenia. Do drugiej grupy należą elementy związane $\mathrm{z}$ wolną wolą, wyborem $\mathrm{i}$ autonomią. Trzecia natomiast, podkreśla wagę zagadnień związanych z funkcjonowaniem układu nerwowego (przeżywanie bólu).

Naturalistyczna koncepcja osoby prowadzi do określonych konsekwencji. W świetle przyjętych założeń należy bowiem uznać za osoby nie tylko tych, którzy przynależą do rodzaju ludzkiego, co szczególnie podkreśla Singer. Istoty, u których można wykazać, że posiadają jakieś zręby racjonalnych władz i samoświadomości, i które są zdolne do odczuwania bólu, w świetle tej koncepcji należy również traktować jako osoby. Odwracając tę tezę należy stwierdzić, że istoty przynależące do rodzaju ludzkiego (human beings), które jednak aktualnie nie dysponują tymi władzami, mogą nie kwalifikować się jako osoby ${ }^{16}$. Singer przykładowo wskazuje tu na ludzi pogrążonych w śpiączce, albo znajdujących się $\mathrm{w}$ stanie wegetatywnym, jednostki z ciężkim upośledzeniem, z częściowym zanikiem funkcji mózgowych, embriony czy nawet noworodki ${ }^{17}$.

Podział na osobę i człowieka jest dla naturalizmu argumentem centralnym. Jak pisze Hellsten, gdyby potraktować jako takie centralne kryterium naturę ludzką (humanity), a nie osobowość (personhood), wówczas ulegamy niebezpieczeństwu speciesyzmu, który kieruje się tautologiczną tezą, że „ludzkie życie posiada szczególną wartość tylko dlatego, że jest ludzkim życiem" ${ }^{18}$. Jak dalej kontynuuje Hellsten, tego typu tautologia jest dla naturalistów przesłanką trudną do usprawiedliwienia; jest tak ponieważ odrzucają oni wyraźnie wszelkiego typu „wyższe prawdy", takie jak wola Boża, czy wewnętrzny cel natury, i chcą prowadzić dyskusję wyłącznie na płaszczyźnie myślenia racjonalno-empirycznego i świeckiego ${ }^{19}$.

\section{Komunitaryzm o osobie}

Ujęcie osoby w myśli komunitariańskiej zdominowane jest przez tendencję przeciwną do naturalizmu. Chodzi mianowicie o zerwanie $\mathrm{z}$ atomistycznym indywidualizmem, właściwym dla definicji empirycznych. Realizacja tego projektu

\footnotetext{
16 W tym kontekście znamienna jest wypowiedź Singera, który stwierdza, że „kiedy myślę o sobie, jako o osobie, którą aktualnie jestem, zdaję sobie sprawę, że nie zaistniałem, jako taki w momencie urodzin lecz dopiero po pewnym czasie od tego faktu. W momencie urodzin nie posiadałem bowiem poczucia czasu, ani żadnego typu doświadczeń, które teraz uznałby za „moje”. Jeśli chodzi o prawo do życia, to liczy się początek życia osoby, a nie początek zaistnienia organizmu biologicznego". Zob. H. Kunse, P. Singer, Should the Baby Live? The Problem of Handicapped Infants, Oxford University Press, Oxford 1985, 133.

17 Singer, Practical Ethics, dz. cyt., 175-217.

18 Hellsten, Towards an Alternative Approach to Personhood in the End of Life Questions, dz. cyt., 518.

19 Tamże
} 
dokonuje się poprzez przesunięcie akcentu z osoby, ujmowanej w sobie samej, na osobę w jej relacji do społeczności. Jak stwierdza jeden z czołowych przedstawicieli tego nurtu myślenia M. Kuczewski, „komunitariański pogląd na osobę widzi „ja” (self), jako istotę konstytuowaną przez funkcje (role) społeczne, wspólne praktyki i poprzez świadomy udział w wymianach czy zaangażowaniach (shared deliberative exchanges) ${ }^{20}$. Ta definicja bardzo ściśle odwołuje się do założenia, że człowiek jest zawsze zakorzeniony w jakiejś społeczności. Ujmowanie samego siebie ,jest nierozłączne od rozumienia siebie jako osoby (...), która jest członkiem tej rodziny, wspólnoty czy narodu, która jest również nosicielem tej historii, która jest synem lub córką tej rewolucji, która jest wreszcie obywatelem tej republiki"21.

Komunitariańska koncepcja osoby nie ujmuje jej więc jako indywidualnego „ja”. Jak stwierdza Hellsten, „Zamiast tego wartość i wola pojedynczego człowieka ma być stale rozpoznawana przez innych, jako że samoświadome „ja” już nie istnieje"22. Pojedyncze charakterystyki takie jak ciało (i jego funkcje) czy ciągłość procesów psychicznych, które w myśli naturalistycznej były elementami konstytutywnymi, w opinii myślicieli związanych z komunitaryzmem, nie posiadają statusu rozstrzygającego. Jak stwierdza Kuczewski, „osoba przechodzi przez wszystkie te stadia, rozwijając osobowe preferencje i nabywając wartości. (...) Wspomagająca rola wspólnoty w tym procesie odkrywania jest częścią (komponentem) tego procesu prawie tak istotną, jak jedyna (niepowtarzalna) konstelacja atrybutów i uczuć jednostki”23.

To socjologiczne (uzależnione od funkcji społeczności) rozumienie osobowość oznacza, że osoba jest raczej identyfikowana z tożsamością trwającej jednostki, niż z jakimś wewnętrznym atrybutem, własnością, którą się posiada stale lub tylko w pewnych okresach życia. Trwanie jednostki osadzone jest w szeroko rozumianych relacjach społecznych i to one w ostateczności są gwarancją i zabezpieczeniem statusu osobowego poszczególnych ludzi, członków wspólnoty. Konsekwencją tego ujęcia jest to, że nie czynniki świadomościowo-wolitywno-neurologiczne są kryterium życia osobowego, ale trwanie określonych wspólnot. W dalszej kolejności oznacza to, że na przykład fakt utraty samoświadomości czy nawet śmierci, nie pozbawia jednostkę jej statusu osobowego, o ile nadal istniej wspólnota, do której ona poprzednio należała ${ }^{24}$.

20 M. Kuczewski, Can Communitarianism End to Shrill and Interminable Public Debates? Abortion as a Case-in-Point, w: Bioethics. Ancient Themes in Contemporary Issues, red. M. Kuczewski, R. Polansky, A Bradford Book. The MIT Press, Cambridge 2000, 182.

21 M. J. SANDEL, Liberalism and the Limits of Justice, Cambridge University Press, Cambridge 1982, 179.

22 Hellsten, Towards an Alternative Approach to Personhood in the End of Life Questions, dz. cyt., 526.

${ }_{23}$ M. Kuczewski, Whose Will Is It, anyway? A Discussion of Advance Directives, Personal Identity, and Consensus in Medical Ethics, „Bioethics” vol. 8(1994) 1, 44.

24 Hellsten, Towards an Alternative Approach to Personhood in the End of Life Questions, dz. cyt., 526. 
To komunitariańskie ujecie osoby nie rozwiązuje jednak wszystkich problemów, jakie pojawiły się w nurcie naturalistycznym. Jeśli bowiem ktoś nigdy nie stał się świadomym członkiem określonej społeczności, z racji, na przykład, wad rozwojowych, taki ktoś jest niemalże automatycznie pozbawiony osobowego statusu istnienia. Chodzi tu szczególnie o jednostki, u których nigdy nie nastąpiło właściwe ukształtowanie układu mózgowo-nerwowego. Drugim problemem, jaki nastręcza ta koncepcja jest fakt jakości relacji w obrębie określonych wspólnot. Nie wiadomo bowiem, czy należy uznać za osoby te jednostki, z którymi dana społeczność posiada słabe relacje, albo którzy egzystują poza tymi formalnymi środowiskami ${ }^{25}$. Chodzi tu o ludzi żyjących w jakimś typie izolacji, takich jak bezdomni, biedni czy ludzie prowadzący alternatywny styl życia.

Komunitariańskie rozumienie osoby - jak to krytycznie ocenia Hellsten - $\mathrm{w}$ istocie nie wiele różni się od ujęcia naturalistycznego. W myśleniu empirycznym za zasadnicze kryterium życia osobowego uznano jakość funkcjonowania układu nerwowo-mózgowego, które gwarantowało zdolność do zaistnienia świadomości i wolnej woli. W komunitaryzmie nadal mamy do czynienia z tym samym rodzajem probierza, pomimo przeciwnych deklaracji myślicieli tego nurtu. Jak stwierdza Hellsten, „komunitarianie dostrzegają wartość osobowości poszczególnej jednostki tak długo, jak długo określona wspólnota uzna ją za wartościowego agenta moralnego. Oznacza to, że posiadanie tego statusu trwa tak długo, jak długo człowiek istnieje w pamięci danej społeczności”26. Następuje więc przesunięcie akcentu ze świadomości jednostkowej, właściwej dla myślenia naturalistycznego, na świadomość zbiorową. Zanik pamięci (świadomości) zbiorowej, który może nastąpić w danej społeczności, jest wówczas równoznaczny z zanikiem statusu osobowego członków społeczności.

Przykładem myśliciela, który w swoisty sposób ukazuje łączność naturalizmu $z$ komunitaryzmem jest $\mathbf{H}$. T. Engelhardt. Jest on tym bioetykiem, który - akceptując przedstawione przez naturalizm charakterystyki osoby - dodaje dodatkowe społeczne rozumienie tego pojęcia. W swojej koncepcji bioetyki laickiej wskazuje on na dwutorowe rozumienia osoby. Z jednej strony osobą jest ta istota, która posiada odpowiednio ukształtowany układ nerwowo-mózgowy i dzięki temu posiada świadomość samej siebie i zdolność do dokonywania wyborów (aktualne osoby, agenci moralni). $\mathrm{Z}$ drugiej strony - $\mathrm{i}$ to jest nowym rozumieniem tego pojęcia - Engelhardt mówi o osobie, jako o kimś kto uzyskuje taki status na mocy decyzji społeczności aktualnych osób. Bioetyk ten odnosi to rozumienie osobowości do istot ludzkich, które jeszcze nie posiadają odpowiednio ukształtowanych władz umysłowo-wolitywnych (embriony, noworodki i małe dzieci), albo do tych, którzy już utracili te własności, wskutek wypadków czy też proce-

5 Tamże.

26 Tamże, 527. 
su starzenia. Z punktu widzenia kryteriów naturalistycznych, istotom tym nie przysługuje ranga bycia osobą, ale ze względu na ich znaczenie dla osób w sensie ścisłym, otrzymują one ten status ${ }^{27}$. Oznacza to, że społeczność, wpólnota aktualnych osób poniekąd nadaje znaczenie osobowe tym, którym na mocy samych mechanizmów biologicznych czy psychicznych ten status nie przysługuje. Może tak być na przykład ze względu na znaczenie tego „przedosobowego" życia dla aktualnych osób ${ }^{28}$ albo dla relacji pomiędzy nimi. Mamy tu więc do czynienia z koncepcją, która pokazuje w jaki sposób naturalistyczne ujmowanie osoby może koherentnie łączyć się z rozumieniem socjologiczno-komunitariańskim.

Na tym poziomie analiz narzuca się już parę istotnych wniosków. Pomimo deklaracji Jonsena o porzuceniu ogólnych teorii na rzecz szczegółowych problemów, dostrzegamy, że bioetyka nie jest w stanie całkowicie zrezygnować z posługiwania się ogólnymi, ale istotnymi koncepcjami. Przykładem tego jest omawiane tu zagadnienie osoby, które stale intryguje niemałą grupę wybitnych bioetyków. Drugi wniosek dotyczy metodologii podejścia do koncepcji osoby. Deklarowana przez myślicieli empirycznych chęć uwolnienia się od „wyższych prawd” (takich jak wola Boża, czy wewnętrzny cel natury) w istocie rzeczy kończy się nie tyle ich wyeliminowaniem, ile zmianą postaci, w jakiej są one obecne. Można bowiem dostrzec, że jeśli nie analizuje się osoby $\mathrm{w}$ aspekcie transcendentnym, czy w świetle najbardziej ogólnych twierdzeń ontycznych, to ujmuje się ją z punktu widzenia nauk empirycznych czy socjologicznych. Oznacza to, że w miejsce tego, co do tej pory uważano za „wyższe prawdy” wchodzi nowy typ „wyższych prawd”, tylko że tym razem prawdy te bardziej odzwierciedlają współczesne tendencje myślenia.

Trzeci wniosek dotyczy już ściśle przedstawionej tu koncepcji osoby. Ujmując w szerszej perspektywie koncepcję naturalistyczną i komunitariańską jako jeden projekt, należy stwierdzić, że mamy tu do czynienia ze swoistym błędem o charakterze metodologicznym. Polega on na tym, że naturaliści i komunitarianie dokonują „pomieszania koncepcji 'osobowości', jako czegoś co jest zmienne (variable) i nieistotne (non-essential) z koncepcją 'osoby', która jest niezmienna (invariable) i posiada charakter koniecznościowy (essential)”29. Inaczej mówiąc następuje tu utożsamienie osobowości w znaczeniu psychologicznym (personality) z osobowością w znaczeniu filozoficzno-ontycznym (personhood).

27 H. T. Engelhardt, Medicine and the Concept of Person, w: What Is a Person?, red. M. F. Goodman, Human Press, New Jersey 1988, 175.

28 W swoim głównym dziele Engelhardt stwierdza: „jeśli ludzki zarodek posiada wyższy moralny status niż zwierzę na zbliżonym poziomie rozwoju, (...) to będzie tak ze względu na znaczenie tego życia dla kobiety, która je poczęła, albo dla innych osób zainteresowanych tym życiem, albo ze względu na przyszłą osobę, która będzie mogła powstać". Zob. H. T. EnGELHARDT, The Foundations of Bioethics, Oxford University Press, New York 1996, 255.

29 Doran, Person - A Key Concept for Ethics, dz. cyt., 41. 
Wobec niemożliwości rezygnacji z ogólnej problematyki w analizach bioetycznych, która łączy się z koniecznością posługiwania się prawdami uniwersalnymi („prawdami wyższymi”), i wobec tendencji do psychologizowania zasadniczych zagadnień filozoficznych, należy jednoznacznie powrócić do ściśle rozumianych analiz filozoficznych omawianej tu koncepcji osoby. Próbą taką podjął niemiecki bioetyk L. Honnefelder.

\section{W stronę koncepcji humanistycznych}

Honnefelder oparł swoje analizy na myśl I. Kanta. Zakwestionował on tezę, że dokonanie oceny komu przysługuje status osoby, a kto jest go pozbawiony zależy od wyselekcjonowanych charakterystyk. Jego zdaniem trudno jest wytłumaczyć dlaczego poszczególne elementy (aspekty) właściwe ludzkiej egzystencji posiadają wewnętrzną, moralną wartość i są zastosowane jak kryteria normatywne w ustalaniu czy ktoś jest czy nie jest osobą, a inne są pominięte. Dlatego Honnefelder proponuje, aby cały proces analiz odnieść nie do jednostki jako członka gatunku, ale do człowieka jako podmiotu moralnego ${ }^{30}$.

Łączy się to z jednoznacznym odrzuceniem tak preferowanego przez naturalistów podziału na człowieka (human being) i osobę (person). Bycie uznanym za człowieka (human being) jest równoznaczne $\mathrm{z}$ byciem kryterium dla podmiotu moralnego. Stąd Honnefelder bardzo stanowczo obstaje przy tezie, że „bycie osobą i przynależność do gatunku ludzkiego są uznawane za nierozłączne (inseparable)"31. Ten typ myślenia idzie po linii rozumowania Kanta. Filozof ten wypowiadając się na temat etycznych implikacji wypływających z takiego postrzegania człowieka, w drugim imperatywie, stwierdza: „Postępuj tak, byś człowieczeństwa tak w twej osobie, jako też w osobie każdego innego używał zawsze zarazem jako celu, nigdy tylko jako środka"32. Tak więc ten kategoryczny imperatyw rozumu potwierdza, że człowieczeństwo jest nierozdzielnie złączone z osobą, stanowiąc podmiot moralny, który jest celem samym w sobie.

Honnefelder definiuje w końcu osobę, jako podmiot moralny, który określa się nie tylko poza perspektywą naturalistyczną (biologiczną), ale także poza ujęciami metafizycznymi. Chodzi o to, aby wskazać na koncepcję osoby, jako pojęcie praktyczne (a practical concept), które nie tyle wywodzi się z metafizyki (is not culled from metaphysics), ile posiada swoje własne i oryginalne znaczenie ${ }^{33}$. Wówczas osoba jest widziana jako „podmiot zdolny do określenia swoich własnych celów i wzięcia odpowiedzialności za nie”; co inaczej mówiąc wskazuje na

\footnotetext{
30 L. Honnefelder, The Concept of a Person in Moral Philosophy, w: Sanctity of Life and Human Dignity, red. K. Bayertz, Kluwer Academic Publishers, Dordrecht 1996, 144.

31 Tamże.

32 I. Kant, Uzasadnienie metafizyki moralności, tłum. M. Wartenberg, Warszawa 1984, 62.

33 Honnefelder, The Concept of a Person in Moral Philosophy, dz. cyt., 146.
} 
osobę jako „jednostkę ludzką, do której może być zastosowana nie limitowana lista predykatów umysłowych i materialnych, które się wzajemnie implikują" ${ }^{34}$.

Propozycja Honnefeldera radykalnie różni się od rozwiązań naturalistycznych. Jest to przede wszystkim wynikiem spojrzenia na osobę z punku widzenia europejskiej filozofii kontynentalnej, a ściślej mówiąc, z punktu widzenia filozofii niemieckiej. W tej perspektywie człowiek postrzegany jest bardziej w świetle szczytowych możliwości i osiągnięć właściwych dla swojego bytu. Jest to przeciwne podejście w stosunku do tego, które funkcjonuje w myśli anglojęzycznej, gdzie istota ludzka definowana jest $\mathrm{w}$ aspekcie swoich minimalnych potencjalności i aktywności.

Wydaje się jednak, że koncepcja ta, zrywając z myśleniem empirystycznym, ma tendencję do pewnego spirytualizowania osoby ludzkiej. Podejrzenie to wynika $\mathrm{z}$ faktu, że człowiek postrzegany jest jako autonomiczny ośrodek, który na mocy posiadanych umysłowych władz, określa sam siebie, swoje cele. Wątpliwa pozostaje tu natomiast kwestia dotycząca ludzkiej cielesności. Wygląda na to, że podmiot moralny-osoba stwarza swoje cele, również te związane z funkcjonowanie ludzkiego ciała. W bioetyce funkcja ludzkiej cielesności (pozytywna funcja ludzkiej cielesności) jest zagadnieniem niezmiernie istotnym ${ }^{35}$. Stąd wskazanie na koncepcję, która może wydawać się nieco kontrowersyjna pobudza do poszukiwania dalszych, bardziej adekwatnych ujęć osoby ludzkiej.

\section{Bioetyka personalistyczna o osobie}

W ramach podejścia personalistycznego istnieje parę stanowisk, które operują pojęciem osoby. Ściśle rzecz biorąc termin ten nie może być uznany za jedno z pojęć właściwych dla szeroko rozumianej dziedziny nauk eksperymentalnych ${ }^{36}$. Dlatego wydaje się, że wspólnym poglądem podzielanym przez filozofów-personalistów jest przekonanie, iż „taki predykat jak 'osoba' (...) nie jest pojęciem empirycznym, naukowym, a więc nie posiada charakteru deskryptywnego, ale

\footnotetext{
34 Tamże, 156.
}

35 Doucet zwraca na to uwagę w kontekście całej bioetyki, stwierdzając: One critical and prophetic task for ethics is to reintegrate the body into our vision of the human being and of the subject of research. Zob. H. Doucet, The Concept of Person in Bioethics, w: Personhood and Health Care, red. D. C. Thomasma, D. N. Weisstub, C. Herve', Kluwer Academic Publishers, Dordrecht 2001, 127.

36 Bellino przywołując stanowisko C. Vigna wskazuje, że z żadnych wypowiedzi deskryptywnych - właściwych dla nauk eksperymentalnych - typu: 'x jest świadome', 'x cierpi', 'x się cieszy', nie wynika logicznie, iż ' $x$ jest osobą'. Zob. F. Bellino, Problemi della bioetica e rispetto della persona, w: Antropologia e bioetica. Ricerca interdisciplinare sull'enigma uomo, red. B. Mondin, Massimo, Milano 1997, 106. 
jest predykatem o charakterze moralnym, ontologicznym i metafizycznym" ${ }^{37}$. Przegląd niektórych propozycji antropologicznych właściwych dla tego postrzegania człowieka powinien uwidocznić przemawiające za tym racje.

Wydaje się, że najbardziej klasycznym rozumieniem osoby w bioetyce, które idzie po tej lini myślenia, operuje E. Sgreccia. W jego przekonaniu „osoba ludzka dla bioetyki jest wartością fundamentalną, kryterium rozeznania i celem samym działania moralnego" ${ }^{38}$. W swoim głównym dziele myśliciel ten stwierdza, że „punktem ciężkości zagadnienia osoby jest zdefiniowanie jej w obrębie konstytuującej ją rzeczywistości, poza samą świadomością właściwą wszystkim osobom i poza możliwościami ekspresyjnymi, które nabywa każda jednostkowa osobowość w procesie dojrzewania"39. Wypowiedź ta dosyć jasno sugeruje, że definiując pojęcie osoby Sgreccia chce wykorzystać narzędzia właściwe dla analiz metafizycznych.

Przedstawiając swoje rozumienie osoby, Sgreccia przywołuje myśl Boecjusza, jako konieczny punkt wyjścia we właściwym zrozumieniu tego istotnego terminu. Boecjusza (V-VI w.) sformułował definicję osoby w kontekście sporów chrystologicznych. W dziele De duabus naturis et una persona Christi, podał on następującą definicję: persona est rationalis nature individua substantia. W określeniu tym można wyróżnić trzy zasadnicze elementy charakteryzujące osobę: osoba jest substancją, jest bytem niepowtarzalnym (indywidualnym) oraz osoba posiada naturę rozumną.

Substancjalność osoby wskazuje na jej realne bytowanie. Sgreccia tak określa ten aspekt życia osobowego: „Osoba jest (...) bytem realnym (materią pierwszą w terminologii Arystotelesa), szczególnym istnieniem, które konkretyzuje w pojedynczym indywiduum rodzaj ogólny i abstrakcyjny istoty (materia wtórna). Istnienie wskazuje na egzystowanie osoby w sobie i przez siebie, na mocy własnego aktu istnienia" ${ }^{\prime 0}$.

37 F. Bellino, Bioetica e principi del personalismo, w: Bioetica fondamentale e generale, red. G. Russo, Societa' Editrice Internazionale, Torino 1995, 93. Palazzani potwierdza tę tezę stwierdzając, że „uznanie statusu osobowego istoty ludzkiej oznacza możliwość powiedzenia czegoś więcej o człowieku niż wskazuje na to sam zbiór cech empirycznych bytu ludzkiego. Rzeczywiste utożsamienie ludzkiego istnienia z osobą wyraża, na poziomie filozoficzno-antropologicznym, charakter własny człowieka i jego cechy konstytutywne. Dzięki temu można wskazać, w ostatecznej instancji, na fundament jego wartości i jego praw oraz obiektywny fundament powinności szacunku i ochrony”. Zob. L. PAlazzani, Il concetto di persona tra bioetica e diritto, G. Giappichelli Editore, Torino 1996, 220.

38 E. Sgreccia, La bioetica personalista, w: Le radici della bioetica, red. E. Sgreccia, V. Mele, G. Miranda, t. I, Vita e Pensiero, Milano 1998, 96.

39 E. Sgreccia, Manuale di bioetica, t. I., Vita e Pensiero, Milano 1991, 78.

40 E. Sgreccia, La persona umana, w: Bioetica, red. C. Romano, G. Grassani, UTET, Torino 1995, 191. 
Charakter indywidualny istnienia osoby określa ją jako byt niepowtarzalny, który się wyróżnia od innych osób poprzez swą cielesność. Sgreccia wskazuje tu na cielesność jako na moment materializowania formy (la materializzazione della forma); z drugiej strony cielesność widziana jest jako nadanie istnienia istocie (lesistenzializzazione dell'essenza) i jako moment, w którym cielesność jest wcieleniem ducha (l'incarnazione dello spirito $)^{41}$.

Natura rozumna osoby pozwala jej na racjonalne podejście do świata, wyrażające się w możliwości dokonania uogólnień, abstrakcji, tworzenia projektów i ujmowania sensu rzeczy. Jak zauważa Sgreccia, osoba ludzka dysponuje nie tylko racjonalnością aktywną, ale przede wszystkim do jej natury należy bycie racjonalną. Oznacza to, że gdy człowiek, na przykład z racji stanu zdrowia, nie przejawia czynnych aktów racjonalnych nie oznacza to utraty racjonalności. Akty są tylko manifestacją racjonalnej natury, ale jej nie wyczerpują ${ }^{42}$.

Zaprezentowana przez E. Sgreccia klasyczna koncepcja osoby zrywa radykalnie z rozumieniem tej kategorii przedstawionym przez naturalistów, a znacznie rozszerza rozumienie tej koncepcji w stosunku do propozycji Honnefeldera. Podstawowym elementem różnicującym ten projekt jest tendencja do ujmowania osoby ludzkiej w sposób integralny, jako niepodzielnej całości. Wyraża się to w opisywaniu człowieka za pomocą ontycznego terminu substancji, która posiada rozumną naturę.

Podejście to bliskie jest innym myślicielom personalistycznym. Jednym $\mathrm{z}$ nich jest W. E. May, który wyraźnie sprzeciwia się dwu powyższym tendencjom (naturalistycznej i idealistycznej) podkreślając integralną przynależność ludzkiego ciała do istoty bycia osobą. Stwierdza on, że „życie nie jest jednym z wielu procesów; nie jest procesem, który może być porównany do oddychania, czucia, wybierania, mówienia i tak dalej. Raczej życie osoby nie może być odróżnione od prawdziwej rzeczywistości osoby: przenika ono wszystkiej jej elementy (części) i aktywności (działania). Osoba ludzka jest kimś więcej niż ludzkie ciało, ale ciało osoby ludzkiej jest integralną częścią jej bycia osobą. Kiedy to ciało umiera, umiera osoba"43.

Wypowiedź ta prowadzi do wysunięcie tezy, która bardzo jednoznacznie uderza tak w naturalistyczne, jak i idealistyczne myślenie o osobie. May wskazuje bowiem na fakt, że podstawową ludzką aktywnością, aktywnością osoby jest nie posiadanie, ale spełnienie swojego istnienia ${ }^{44}$. Formułując to nieco ogólniej można stwierdzić, że reistyczne odniesienie do cielesności czy to poprzez określanie jej jako wyłącznej domeny procesów empirycznych czy to poprzez czynie-

41 Tamże.

42 Tamże.

43 W. E. May, Bioethics and Human Life, w: Natural Law and Contemporary Public Policy, red. D. F. Forte, Georgetown University Press, Washington, D. C. 1998, 48.

44 Tamże. 
nie jej wyłącznym przedmiotem kreatywnej aktywności podmiotu zostaje wykluczone. Cielesność w tej perspektywie nie jest czymś, co osoba posiada i czym może dysponować jako rzeczą (również dysponować poprzez traktowanie ciała jako rzeczywistości wyłącznie biologicznej). Ludzkie ciało posiada wewnętrzną wartość osobową - jest elementem konstytutywnym osoby, zewnętrzną (ale nie odseparowaną, nie heteronomiczną) manifestacją życia osobowego.

Przypisywanie ludzkiej cielesności wewnętrznej, osobowej wartości łączy się ściśle ze wskazaniem na jej wewnętrzny cel. Jeśli bowiem nie jest to rzeczywistość subosobowa, rządzona wyłącznie procesami o charakterze biologicznym, wówczas jako element konstytuujący osobę, cielesność posiada swoje wewnętrzne cele, które są zarazem celami życia osobowego, celami osoby. Dopiero w tym kontekście można zrozumieć przedstawioną powyżej dystynkcję pomiędzy „posiadaniem”, a „spełnieniem”. Cielesność nie jest przedmiotem do posiadania, ale partycypuje w ludzkim spełnieniu.

Wskazanie na jedność aspektu cielesnego i duchowego osoby jest wyraźnym przeciwstawieniem się dualizmowi funkcjonującemu we współczesnej bioetyce: osoba to świadomość i wolność, albo osoba to cielesność z całą gamą konstytuujących ją procesów empirycznych ${ }^{45}$. Wykazanie, że ta alternatywa w konsekwencjach jest zgubna dla bioetyki, jest celem analiz filozoficznych niemieckiego personalisty R. Speamanna. Próbuje on wykazać, że pomiędzy pojęciem osoby, a pojęciem człowieka istnieje ścisła zbieżność. Stwierdza on: „Może istnieć tylko jedno kryterium bycia osobą: biologiczna przynależność do rodzaju ludzkiego. Dlatego też początku i końca istnienia osoby nie można oddzielić od początku i końca ludzkiego życia. Jeśli „ktoś” istnieje, to istniał, od kiedy zaistniał ten oto indywidualny ludzki organizm, i będzie istniał tak długo, jak długo organizm ten jest żywy. Byciem osoby jest życie człowieka. (...) Osoba bowiem jest człowiekiem, a nie jakąś cechą człowieka" ${ }^{\prime \prime 6}$. Ta ostatnia teza nawiązuje do przedstawionej powyżej myśli May’a. Osoba nie jest cechą, czy rzeczą którą można określić za pomocą takich czasowników jak nabywanie, tracenie, dysponowanie, ulepszanie czy też pogarszanie (zubożanie). Wszystkie te kwalifikatory dotyczą najwyżej cech osobowych, w znaczeniu psychologicznym, a nie filozoficznym. Jednostce ludzkiej przysługuje niezmiennie status osoby tak długo, jak długo jest człowiekiem. Bycie natomiast człowiekiem, bycie „kimś” jest radykalnie odmiennym sposobem egzystencji, niż jest to właściwe rzeczy, jako bycie „czymś”.

Dla eksplikacja tej tezy można posłużyć się myślą polskiego personalisty i fenomenologa K. Wojtyły. Bardzo jednoznacznie wskazuje on, że „człowiek jest przedmiotowo „kimś” - i to go wyodrębnia wśród reszty bytów widzialne-

\footnotetext{
45 Zagadnieniu temu poświęca głębszą uwagę B. Chyrowicz, opisując i analizując ten problem jako separację natury od osoby. Zob. B. Chyrowicz, Bioetyka i ryzyko, Lublin 2000, 227nn.

46 R. Spaemann. Osoby. O różnicy między czymś a kimś, tłum. J. Merecki, Warszawa 2001, 305.
} 
go świata, które przedmiotowo są zawsze tylko „czymś”. To proste, elementarne rozróżnienie kryje w sobie głęboką przepaść, jak dzieli świat osób i rzeczy" ${ }^{37}$. Niewątpliwie teza ta odwołuje się do swoistej intuicji człowieka, która ujmuje go jako istotę nieredukowalną do innych bytów. Jeśli bowiem o wszystkim co istnieje można orzekać w kategoriach nabywania, tracenia, dysponowania, ulepszania czy pogarszania, to w odniesieniu do osoby wydaje się to być wyraźnie nieadekwatne; odniesienie tego do człowieka jest dopuszczalne najwyżej w znaczeniu przenośnym, albo gdy bierze się pod uwagę bardzo określone aspekty ludzkiego życia (np. można ulepszać osobowość w znaczeniu psychologicznym czyli cechy osobowości). Ujęcie osobowości rozumianej filozoficznie ${ }^{48} \mathrm{w}$ kategoriach jakościowo-ilościowych wyraźnie godzi więc w intuicyjne poczucie wielkości i niepowtarzalności ludzkiej osoby. Odwołując się do myślenia analogicznego można stwierdzić, że intuicję tę dobrze wyraża zasada wyłączonego środka. Pomiędzy byciem osobą, a byciem bytem nieosobowym nie istniej żaden stan pośredni. Nie można być tylko w części osobą, albo być intensywniej lub mniej intensywniej osobą. Należy również wykluczyć ujmowanie osoby poprzez wskazywanie na gradację stawania się. Jeżeli można nawet mówić o stopniowalności stawania się, to tylko w znaczeniu epistemicznym, a nie ontycznym - wskazując na etapy ujawniania się osoby. Ujmując to w skrócie można więc powiedzieć, że jeśli coś zaistniało, od początku zaistniało jako byt osobowy, albo jako nieosobowy.

\section{Zakończenie. Osoba w analizach bioetycznych}

Przedstawione różne propozycje ujmowania osoby ludzkiej potwierdzają, że problem ten jest stale ważny i trudno byłoby mówić o zakończeniu dyskusji wokół tego zagadnienia. Jego doniosłość wynika przede wszystkim z tego - jak wskazano na wstępie - że właściwie większość problemów bioetycznych dotyczy człowieka. Dlatego każda próba rozwiązania szczegółowych zagadnień odwołuje się otwarcie lub domyślnie do jakiegoś rozumienia człowieka-osoby.

47 K. WojtyŁa, Miłość i odpowiedzialność, Lublin 1986, 24. Inny personalista-fenomenolog odnosząc się do tego istotnego rozróżnienia i przywołując subiektywne doświadczenie samego siebie, pyta: „Czy nie możemy powiedzieć, że chociaż doświadczamy nas samych, jako zanurzonych w świat rzeczy dokoła nas, być może nawet jako „jedną część” z nimi, to jednak my jako osoby nie jesteśmy $w$ rzeczywistości jedną częścią z czymkolwiek, ale raczej jesteśmy w sposób niekomunikowalny sami sobą a nie innymi; i że to subiektywne samodoświadczenie (nas jak zanurzonych w świat rzeczy), dane w stanach rozproszenia jest w sprzeczności z tym, kim my jako osoby rzeczywiście jesteśmy?” Zob. J. F. Crosby, The Personhood of the Human Embryo, „The Journal of Medicine and Philosophy” 18(1993) 4, 402.

$48 \mathrm{~W}$ jezyku angielskim ta dystynkcja jest sygnalizowana za pomocą dwu odmiennych terminów: personhood - osoba w znaczeniu filozoficznym, personality - osoba jako psychologicznie rozumiana osobowość. 
Naszkicowane koncepcje bazują na różnych kryteriach osobowości (personhood). Z jednej strony, wskazuje się na kryteria związane z funkcjonowaniem układu nerwowo-mózgowego, które są podstawą do somatycznego zaistnienia świadomości jednostkowej czy, konsekwentnie, zbiorowej. Do tej grupy należą także czynniki decydujące o autonomii jednostki. Mają one, ogólnie rzecz biorąc, charakter empiryczny: wskazują najwyżej na psycho-somatyczne aspekty osoby ${ }^{49}$. Z drugiej strony, wskazuje się na kryterium osoby jaką jest podmiotowość moralna. To ujęcie $\mathrm{z}$ kolei idzie $\mathrm{w}$ drugą stronę i posiada tendencję do spirtualizowania człowieka-osoby (człowiek jako autokreatywny duch).

Stanowiskiem, które wydaje się być bardziej adekwatnym rozwiązaniem tego zagadnienia $\mathrm{w}$ bioetyce jest personalizm. Ujmuje on jednostkę jako wcieloną podmiotowość. Probierzem, który decyduje o życiu osobowym nie są więc ani czynniki empiryczno-psychiczne ani spirytualistyczne; jest nim natomiast właściwy danej osobie akt istnienia. Formuje on wszystkie bogate fenomeny życia duchowo-podmiotowego, a także przenika te właściwe dla cielesności. Osobowy akt istnienia sprawia, że cielesność partycypuje w życiu osobowym stając się nieodłącznym aspektem osoby. Cielesność - w tej perspektywie - nie jest więc tylko biologicznym organizmem, czy materiałem, przedmiotem dla twórczej funkcji umysłu.

To ostatnie z przedstawionych stanowisk, które może być określone mianem personalizmu ontologicznego, jest bardzo pomocne w rozwiązywaniu nawet skomplikowanych kazusów moralnych w środowisku medycznym. Aby nie sprowadzić ludzkiego życia do jakiś wyselekcjonowanych, pojedynczych charakterystyk - z jednej strony - czy też nie uzależnić jego wartości od, czasami bardzo skomplikowanych, procesów czy procedur instytucjonalnych ${ }^{50}-\mathrm{z}$ drugiej, potrzeba posiadać jasną intuicję osoby, która znajduje właściwe ugruntowanie teoretycznie (metafizyczne i antropologiczne). Posługiwanie się integralnym pojęciem osoby, proponowane przez personalizm ontologiczny, pomaga uporządkować teoretyczne założenia, z którym wchodzi się w gąszcz praktycznych działań i procedur, i ukształtować takie podejście, w którym człowiek-osoba jest w centrum działania terapeutycznego.

49 Teichman określa ten sposób ujmowania osoby jako koncepcję brains-plus-nervous-system. Zob. J. Teichman, The Definition of Person, „Philosophy” 60(1985), 176.

50 Na niebezpieczeństwo to zwraca uwagę Viafora. Zob. C. Viafora, I principi della bioetica, „Bioetica e cultura” II(1993) 3, 34. 


\title{
The Debate on the Concept of a Person in Bioethics
}

\begin{abstract}
SUMMARY
This article endeavours to sketch the debate about the concept of a person in the realm of bioethics. Initially, it sets out three understandings of the issue, namely the concept of a person in a naturalistic philosophy, in the current of communitarianism and in one of the humanistic positions. The analyses of these approaches lead to the conclusion that a human person is perceived either as an empirical and psychological entity or as a free subjectivity creating him/herself. This thesis is stimulation to further research. In order to avoid a kind of dualism in perception of the person stemming from the stances outlined above, the personalistic approach is developed. This points out, that a human being should be depicted as one indivisible entity unifying in itself more strictly self, a subjective aspect of the person, with nature-body aspect which is an objective facet of being human. Given this personalistic perspective, a person comes out as an embodied subjectivity formed by the unique personal act of existence. In this article, such a concept of the person is argued as a vital support in the complex field of bioethical dilemmas.
\end{abstract}

